\title{
HUBUNGAN BUDAYA SEKOLAH DAN KETELADANAN GURU DENGAN KARAKTER SISWA SEKOLAH DASAR NEGERI 050772 KECAMATAN PANGKALAN SUSU KABUPATEN LANGKAT
}

\author{
Khairani Nasution \\ Penulis adalah Mahasiswa Program Magister Pendidikan Agama Islam Fakultas \\ Tarbiyah dan Keguruan UIN SU - Medan \\ E-mail: simpaikablangkat@gmail.com / nst.khairani@yahoo.co.id
}

\begin{abstract}
This research aims to know how the relation of primary School 050772 Pangkalan Susu. The sample of this research 30 student where $21 \%$ taken of 141 students. This research uses data collection tool in the form of Likert scale. Questioner is compiled based on variabel and tested to respondent that is not research sample. Data analysis process is conducted by using quantitative approach through three steps, they are: 1. Describing research variabel data. 2. Testing requirements analysis. 3. Testing hypotesis to reveal the relation the relation beetween research variables using correlation analysis technique. Based on data analysis result and testing process, then the conclusion is (1) the school culture has positive relation with student's character of primary school 050772 Pangkalan Susu. This case is proved that the correlation $r$ $(0,504)>\mathrm{r}$ table $(0,3061)$ while the significance is $0,004<0,05 ;(2)$ the teacher's example has positive relation with student's character of primary School 050772 Pangkalan Susu where correlation coeficient $r(0,603)>r$ table $(0,3061)$ with significncy 0,006, it is fewer than 0,05; (3) School Culture and teacher's example has positive ration with student's character of primary school 050772 Pangkalan Susu where correlation coefisiency $\mathrm{r}(0,662)>\mathrm{r}$ table $(0,3061)$, testing result $\mathrm{F}$ shows that $\mathrm{F}$ count $(10,506)>\mathrm{F}$ table $(3,35)$ while significancy $<0,05$ that is 0,000 . Based on the research above, it can be stated that student's character can be formed through school culture and teacher's example.
\end{abstract}

Keyword: School Culture, Teacher's Example, Student's Character

\section{PENDAHULUAN}

Pemerintah saat ini terus berkomitmen membangun pendidikan karakter bangsa dalam rangka menyiapkan generasi Emas 2045, yang memiliki kecakapan abad 21. Dengan menempatkan karakter sebagai ruh pendidikan di Indonesia. Wujud komitmen tersebut dapat dilihat dari Undang - Undang Republik Indonesia Nomor 20 Tahun 2003 tentang Sistem Pendidikan Nasional pasal 3 Marzuki (2014:90), undang Undang tersebut menjelaskan Fungsi Pendidikan Nasional:

Pendidikan Nasional berfungsi mengembangkan kemampuan dan membentuk karakter serta peradaban bangsa yang bermartabat dalam rangka mencerdaskan kehidupan bangsa, bertujuan untuk berkembangnya potensi peserta didik agar menjadi 
manusia yang beriman dan bertaqwa kepada Tuhan Yang Maha Esa, berakhlak mulia, sehat, berilmu, cakap, kreatif, mandiri, dan menjadi warga negara yang demokratis serta bertanggung jawab. (Sulystyowati, 2012:3)

Tujuan Pendidikan Nasional ini adalah rumusan kualitas manusia Indonesia yang harus diterapkan oleh setiap satuan pendidikan yang merupakan dasar dalam pengembangan pendidikan budaya dan karakter bangsa Hasan dkk (2010:8)

Seluruh elemen bangsa menyadari pentingnya pembangunan karakter bangsa, mengingat semakin merosotnya karakter bangsa Indonesia, jumlah pelaku korupsi semakin bertambah, tingkat kekerasan meningkat, tawuran, antar pelajar, sikap tidak peduli terhadap sesama karena itu pemerintah berusaha agar seluruh kebijakan pemerintah selalu memprioritaskan pembangunan karakter bangsa.

Pemerintah telah berupaya mewujudkan tujuan pendidikan nasional tersebut dengan memasukkan pendidikan karakter kedalam kegiatan pembelajaran siswa. Namun pada kenyataannya dari tahun ke tahun data dan fakta yang kita lihat bahwa terjadinya kemerosotan karakter pelajar Indonesia. Salah satu penyebabnya adalah kegagalan institusi pendidikan dalam menanamkan dan menumbuhkan peserta didik yang berkarakter atau berakhlak mulia. Bila kita melihat materi pelajaran Pendidikan Agama dan Pendidikan Kewarganegaraan sudah sangat bagus namun selama ini pendidikan di Indonesia selalu berorientasi pada pengetahuan akademis saja, sedangkan pengamalan dari materi pelajaran itu sendiri, sikap yang diharapkan pada materi tersebut berupa karakter terabaikan.

Karakter yang diharapkan siswa miliki tidak tumbuh dengan sendirinya, tidak dapat dilakukan secara kebetulan melainkan memerlukan proses, contoh teladan, pembiasaan atau pembudayaan dalam lingkungan peserta didik baik itu lingkungan keluarga, sekolah dan masyarakat. Selayaknya, pendidikan karakter adalah bagian esensial yang menjadi tugas sekolah membentuk pribadi berkarakter peserta didik sebagaimana yang diamanatkan Undang - Undang maka budaya sekolah dan keteladanan guru merupakan hal yang berkaitan langsung dalam pembentukan karakter peserta didik.

Budaya sekolah adalah suasana kehidupan sekolah dimana peserta didik berinteraksi dengan sesama, guru dengan guru, konselor dengan peserta didik, antar tenaga pendidikan, dan antara tenaga pendidik dengan pendidik dan peserta didik, dan 
antar anggota kelompok masyarakat dengan warga sekolah yang terikat dengan berbagai aturan, norma, moral serta etika bersama yang berlaku di suatu sekolah.

Keteladanan guru juga sangat mempengaruhi karakter siswa. Guru tidak hanya menyampaikan materi pelajaran kepada siswa melainkan model, contoh bagi peserta didik dari seluruh kepribadian, sikap/perilaku cara berbicara, berteloransi, bergaul.

Guru adalah personal yang sangat vital dalam memberikan teladan dalam pendidikan karakter disekolah karena sebagian besar interaksi yang terjadi disekolah adalah antara peserta didik dengan guru. Pemahaman dan implementasi sikap guru terhadap pendidikan karakter sangat menentukan keberhasilan implementasi pendidikan karakter di sekolah.

Peneliti merasa sangat urgen bagi sekolah untuk dapat mendesain dan mengembangkan budaya sekolah yang berkarakter dan pentingnya guru memiliki keteladanan sehingga mampu menanamkan dan manumbuhkan karakter bagi peserta didik, tetapi apabila ini terus terabaikan maka krisis karakter yang telah terjadi di negara kita akan terus berlangsung. Tingkat kekerasan dikalangan remaja dan anakanak terus meningkat, kenakalan siswa juga semakin meningkat diawali dengan budaya mencontek, berbohong, membolos, tawuran sampai terlibat dalam seks bebas dan penggunaan narkoba. Dan tanpa kita sadari sikap peduli, tata krama dan etika anak bangsa saat ini terhadap sesama dan lingkungannya semakin menurun. Bila ini yang melanda generasi bangsa, kita tidak dapat membayangkan akan jadi apa negeri ini.

Pemerintah membuat kebijakan dengan mengintegrasikan pendidikan karakter ke dalam setiap mata pelajaran. Dan juga guru sebagai pendidik karakter diberikan pelatihan, bimbingan, pembinaan dan peningkatan kompetensi, kualitas, profesionalisme dan taraf kesejahteraan para pelaku dunia pendidikan. Pemerintah melakukan berbagai upaya tersebut dengan harapan agar orang- orang yang berkecimpung di dalam dunia pendidikan seperti kepala sekolah mempunyai kompetensi dalam membangun sekolahnya. Guru juga mempunyai kompetensi dalam mengajar dan mendidik siswa. Dan bila semua pihak tidak hanya sekolah, tetapi juga keluarga, masyarakat dan lingkungan ikut serta dalam pembentukan karakter anak bangsa, maka kita akan memiliki generasi pemimpin bangsa yang tangguh, beriman dan bertaqwa kepada Tuhan Yang Maha Esa, berbudi luhur, bertoleran, bergotong royong, berjiwa patriotik, berkembang dinamis dan berorientasi ilmu pengetahuan dan teknologi. 
Kementerian Pendidikan Nasional (2010:9) telah menentukan 18 nilai karakter yang harus ditumbuh kembangkan kepada siswa melalui budaya sekolah, yaitu: Religius, jujur, toleransi, disiplin, kerja keras, kreatif, mandiri, demokratis, rasa ingin tahu, semangat kebangsaan, cinta tanah air, menghargai prestasi, bersahabat, cinta damai, gemar membaca, peduli lingkungan, peduli sosial dan tanggung jawab.

Implementasi pendidikan karakter di Sekolah Dasar Negeri 050772 telah dilakukan di sekolah ini, penulis melihat penanaman nilai-nilai sesuai dengan norma-norma agama dan norma-norma di masyarakat seperti para siswa menyalami guru yang berada didepan ketika siswa akan memasuki ruangan kelas. Sebelum dan setelah pelajaran salah seorang siswa dipandu oleh guru memimpin pembacaan doa agar ilmu yang dipelajari nantinya dapat diterima, diamalkan dan bermanfaat bagi seluruh siswa. Siswa juga selalu dianjurkan berpakaian rapi dan menggunakan atribut yang lengkap, menggunakan tali pinggang, sepatu hitam dan memakai kaos kaki. Bila ada siswa yang terlambat maka akan diberikan sanksi dari guru piket. Namun sebagian besar guru tidak mengetahui bahwa yang mereka lakukan itu bagian dari penanaman nilai-nilai karakter siswa

Sekolah seharusnya dapat menanamkan dan menumbuhkan ke 18 nilai karakter yang diharapkan dimiliki siswa sekolahnya. Serta guru mampu memberikan keteladanan nilai-nilai karakter kepada siswa berupa perkataan dan perbuatan. Namun bila ini terus diabaikan maka generasi bangsa akan kehilangan jati diri, identitas karakter bangsa, terlebih-lebih misi pembangunan nasional tidak akan tercapai dan Indonesia akan kehilangan generasi penerusnya.

Berbagai permasalahan di atas mendorong penulis untuk melakukan penelitian berjudul "Hubungan Budaya Sekolah dan Keteladanan Guru dengan Karakter Siswa Sekolah Dasar Negeri050772 Kecamatan Pangkalan Susu Kabupaten Langkat.

\section{METODOLOGI}

Penelitian yang dilakukan ini termasuk penelitian kuantitatif. Penelitian kuantitatif adalah penelitian yang pengolahan datanya menggunakan data-data numerikal (angka) yang diolah dengan metode statistik.

Sehubungan dengan tujuan yang ingin dicapai yaitu menguji hubungan antara budaya sekolah dan keteladanan guru dengan karakter siswa, maka penelitian kuantitatif ini menggunakan pendekatan expost-facto (non eksperimen) dengan 
rancangan kerelasional. Penelitian yang bersifat korelasional merupakan penelitian yang bertujuan menemukan ada tidaknya hubungan, dan apabila ada berapa eratnya hubungan serta berarti tidaknya hubungan tersebut.

Populasi penelitian ini adalah siswa kelas III, IV, V dan VI Sekolah Dasar negeri 050772 Pangkalan Susu yang berjumlah 141 siswa dengan sampel 30 orang yang diambil berdasarkan teknik random sampling. Instrumen yang digunakan adalah skala model Likert.

\section{HASIL PENELITIAN}

Hasil penelitian yang telah dilakukan menunjukkan budaya sekolah sangat baik, hal ini ditunjukkan dengan 3 responden (10\%), 11 responden $(36,3 \%)$ menyatakan budaya sekolah baik, 14 responden (46,2 \%) menyatakan budaya sekolah cukup baik, dan 2 responden (10\%) menyatakan budaya sekolah tidak baik. Begitu juga dengan hasil penelitian pada variabel keteladanan guru sebanyak 2 responden $(6,7 \%)$ menunjukkan keteladanan guru sangat baik, 12 responden (40 \%) menyatakan keteladanan guru baik, 13 responden (43\%) menyatakan keteladanan guru cukup baik, dan 3 responden (10\%) menyatakan keteladanan guru tidak baik. Dengan demikian dapat disimpulkan bahwa kecenderungan keteladanan guru berada pada tingkat yang cukup baik.

Hasil penelitian pada variabel karakter siswa sebanyak 5 responden (17\%) menunjukkan karakter siswa sangat baik, 9 responden (30\%) menyatakan karakter siswa baik, 10 responden (33\%) menyatakan karakter siswa cukup baik, dan 6 responden (20\%) menyatakan karakter siswa tidak baik. Dengan demikian dapat disimpulkan bahwa kecenderungan budaya karakter siswa berada pada tingkat yang cukup baik $(33 \%)$.

\section{PEMBAHASAN}

\section{Hubungan Budaya Sekolah $\left(\mathrm{X}_{1}\right)$ dengan Karakter Siswa (Y)}

Hasil penelitian ini menunjukkan terdapat hubungan signifikan antara budaya sekolah dengan karakter siswa di SDN 050772 Pangkalan Susu. Berdasarkan hal tersebut maka dapat kita ambil kesimpulan bahwa budaya sekolah memberi pengaruh yang positif terhadap karakter siswa. 
Sekolah adalah tempat siswa memperoleh pendidikan dan pengajaran. Dari tidak tau menjadi tau. Selain mencetak generasi intelektual, sekolah juga harus mencetak generasi yang beriman kepada tuhan yang Maha Esa, bertanggung jawab. Oleh karena itu sekolah harus mampu menciptakan dan mengembangkan budaya sekolah untuk membentuk karakter peserta didiknya.

Budaya sekolah merupakan urat nadi suatu sekolah yang harus mendapat perhatian dan pengelolaan yang baik serta dibangun berdasarkan karakteristik budaya lokal masyarakat setempat. Perumusan budaya sekolah dilakukan dengan sebuah komitmen yang jelas dan terukur oleh komunitas sekolah yakni, siswa, guru, manajemen sekolah dan masyarakat.

Sekolah adalah sarana adalah wahana pembinaan dan pengembangan karakter siswa yang dilakukan dengan berbagai cara diantaranya melalui: pendekatn terintegrasi kesemua mata pelajaran, pengembangan budaya sekolah; pengembangan budaya sekolah; pelaksanaan kegiatan kokurikulerdan ekstrakurikuler, sera pembiasaan perilaku dalam kehidupan di lingkungan sekolah

Budaya sekolah adalah pola nilai-nilai dan prinsip-prinsip, tradisi-tradisi dan kebiasaan-kebiasaan yang terbentuk dalam perjalanan panjang sekolah, dikembangkan sekolah dalam jangka waktu yang lama dan menjadi pegangan serta diyakini oleh seluruh warga sekolah.

Paparan data variabel budaya sekolah $\left(\mathrm{X}_{1}\right)$ menunjukkan bahwa sebanyak 3 responden $(10 \%)$ menunjukkan budaya sekolah sangat baik, 11 responden $(36,3 \%)$ menyatakan budaya sekolah baik, 14 responden (46,2 \%) menyatakan budaya sekolah cukup baik, dan 2 responden $(6,7 \%)$ menyatakan budaya sekolah tidak baik. Dengan demikian dapat disimpulkan bahwa kecenderungan budaya sekolah berada pada tingkat yang cukup baik.

Data diatas menunjukkan kecenderungan budaya sekolah pada tingkat yang cukup baik, namun budaya sekolah harus terus dikembangkan dan diinovasi agar peserta didik tidak bosan berada di lingkungan sekolah. Bagaimana menjadikan sekolah sebagai tempat yang aman dan nyaman bagi peserta didik.

Sekolah adalah tempat belajar, tempat memberi dan menerima ilmu pengetahuan. Namun sekolah tidak hanya membentuk peserta didik menjadi orang yang berhasil dari segi akademik saja. Tapi dari segi non akademik juga yang meliputi 
sikap dan perilaku sehingga para lulusan tidak hamya cerdas pikiran, tetapi juga cerdas emosi dan spiritual.

Sekolah harus merumuskan visi, misi dan tujuan sekolah dengan baik. Misi dan misi jangan dianggap sebagai slogan saja. Selayaknya visi dan misi harus dijadikan acuan sekaligus cita-cita yang ingin dicapai suatu sekolah melalui programprogramnya

Upaya-upaya yang dilakukan sekolah dalam rangka mengembangkan budaya sekolah sebagai sarana pembentuk karakter adalah

1. Pendidikan karakter di sekolah harus dilakukan didalam proses pembelajaran yang terintegrasi kepada seluruh mata pelajaran.

2. Pendidikan karakter dikembangkan melalui kegiatan ekstrakurikuler, kegiatan pembinaan kesiswaan merupakan pendidikan di luar mata pelajaran. Melalui kegiatan pembinaan kesiswaan, siswa dapat difasilitasi untuk mengembangkan karakter

3. Membangun komunikasi harmonis antara guru, orangtua dan masyarakat untuk bersama-sama pedulidengan sekolah dan program-programnya.

4. Menyadari bahwa membangun karakter siswa di sekolah tidak hanya tugas guru pendidikan agama, PKN dan guru BP, melainkan tugas seluruh pendidik dan tenaga pendidikan yang tercermin dari perkataan dan perbuatannya.

5. Merencanakan dan melaksanakan program yang tegas dan terperinci dalam pengembangan karakter siswa di sekolah.

6. Lingkungan fisik dan sosial-kultural sekolah, harus dikondisikan sehingga memungkinkan para siswa membangun kegiatan kesaharian di sekolah yang mencerminkan perwujudan karakter yang sesuai dengan amanat Undang Undang.

\section{Hubungan Keteladanan Guru $\left(\mathbf{X}_{2}\right)$ dengan Karakter Siswa (Y)}

Hasil penelitian ini menunjukkan terdapat hubungan signifikan antara keteladanan guru dengan karakter siswa di Sekolah Dasar Negeri 050772 Pangkalan Susu. Berdasarkan hasil penelitian ini dapat dipahami bahwa keteladanan guru sangat berpengaruh positif dan signifikan terhadap karakter siswa. .

Guru Harus menyadari bahwa ia tidak hanya sebagai orang yang mengajarkan ilmu pengetahuan, namun juga harus mampu menanamkan dan mentransfer nilai-nilai 
dari imu pengetahuan tersebut. Sehingga mampu mencetak generasi yang beriman, berakhlak mulia, dan berilmu pengetahuan serta mampu bersaing di era globalisasi ini. Untuk itu guru harus mampu menjadikan dirinya sosok yang layak untuk diteladani, mampu menata dirinya, menjaga perkataan dan perbuatannya, karena apapun yang dilakukannya adalah patron bagi orang lain.

Keteladanan guru adalah suatu perbuatan atau tingkah laku yang baik yang patut ditiru oleh anak didik yang dilakukan oleh seorang guru di dalam tugasnya sebagai pendidik baik tutur kata atau perbuatannya dapat diterapkan dalam kehidupan sehari-hari oleh siswa di mana saja ia berada. Guru yang tidak hanya menjalankan tugasnya dalam mentransfer ilmu pengetahuan saja tetapi juga memiliki kepribadian yang baik, menjadikan dirinya model yang mampu menanamkan nilai-nilai kebajikan dalam kehidupan sehingga terbentuk pribadi siswa yang berkarakter baik.

Keteladanan guru merupakan pilar yang sangat penting dalam pendididkan. Fungsi guru sebagai pendidik di tuntut untuk mampu membentuk dan mewarnai kepribadian siswanya. Sosok pendidik ini harus bisa menularkan karakter baik kepada siswa dengan cara memberikan pemahaman dan pemberian contoh sikap.

Paparan data variabel budaya sekolah $\left(\mathrm{X}_{2}\right)$ menunjukkan bahwa sebanyak 2 responden $(6,7 \%)$ menunjukkan keteladanan guru sangat baik, 12 responden $(40 \%)$ menyatakan keteladanan guru baik, 13 responden (43\%) menyatakan keteladanan guru cukup baik, dan 3 responden (10\%) menyatakan keteladanan guru tidak baik. Dengan demikian dapat disimpulkan bahwa kecenderungan keteladanan guru berada pada tingkat yang cukup baik.

Guru teladan harus guru yang memiliki kepribadian baik, menjalankan tugas dengan profesional, guru yang menjadikan dirinya sosok yang pantas menjadi panutan sehingga menjadi inspirasi bagi orang lain (siswa) untuk melakukan sesuatu. Oleh karena itu keberhasilan pendidikan karakter sangat ditentukan oleh karakter guru yang harus senantiasa berkarakter baik demi tertanamnya karakter baik pada peserta didiknya.

\section{Hubungan Budaya Sekolah $\left(X_{1}\right)$ dan Keteladanan Guru $\left(X_{2}\right)$ dengan Karakter} Siswa (Y)

Hasil penelitian ini menunjukkan terdapat hubungan signifikan antara budaya sekolah dan keteladanan guru dengan karakter siswa di Sekolah Dasar Negeri 050772 
Pangkalan Susu. Berdasarkan hasil penelitian ini dapat dipahami bahwa budaya sekolah dan keteladanan guru sangat berpengaruh positif dan signifikan terhadap karakter siswa Sekolah Dasar Negeri 050772 Pangkalan Susu.

Sekolah merupakan lembaga yang dipercaya untuk mampu menciptakan anak bangsa yang sesuai dengan amanat Undang-Undang sebagaimana disebutkan di atas.

Kesuksesan seseorang tidak hanya ditentukan oleh pengetahuan dan kemampuan teknis (hard skill) saja tetapi lebih banyak ditentukan oleh kemampuan mengelola diri dan orang lain (soft skill). Bagaimana seseorang mampu berkomunikasi baik dengan dirinya, orang lain dan lingkungannnya. Hal tersebut akan terbentuk dari karakter yang baik.

Pendidikan karakter dapat diartikan sebagai kemampuan berfikir, menghayati dalam bentuk sikap dan mengamalkan dalam bentuk perilaku yang sesuai dengan jati dirinya, sehingga tercermin dalam perilaku diri terhadap tuhannya, sesama manusia dan lingkungannya.

Pendidikan karakter adalah usaha sadar dan terencana yang dilakukan oleh guru dalam rangka membentuk karakter peserta didik dengan melalui proses penanaman nilai-nilai dalam berfikir, bersikap yang diharapkan akan tercermin dari perilaku siswa yang diwujudkan dalam interaksi siswa dengan dirinya, Tuhannya, antar sesama manusia dan lingkungannya.

Paparan data variabel budaya sekolah $\left(\mathrm{X}_{2}\right)$ menunjukkan bahwa sebanyak 5 responden (17\% ) menunjukkan keteladanan guru sangat baik, 9 responden $(30 \%)$ menyatakan keteladanan guru baik, 10 responden (33\%) menyatakan keteladanan guru cukup baik, dan 6 responden $(20 \%)$ menyatakan keteladanan guru tidak baik. Dengan demikian dapat disimpulkan bahwa kecenderungan keteladanan guru berada pada tingkat yang cukup baik.

Berdasarkan data di atas bahwa sekolah harus terus mengembangkan budaya sekolah agar pendidikan karakter yang disebut juga pendidikan budi pekerti benarbenar merupakan program pembelajaran di sekolah yang bertujuan mengembangkan watak atau tabiat siswa dengan cara menghayati nilai-nilai dan keyakunan masyarakat sebagai kekuatan moral dalam hidupnya melalui kejujuran, dapat dipercaya, disiplin dan kerjasama Zubaedi (2012:25). 
Guru sebagai teladan harus mampu mengembangkan nilai-nilai karakter siswa sehingga memiliki karakter baik dalam dirinya mampu menerapkan nilai-nilai tersebut dalam kehidupannya sebagai individu dan sebagai anggota masyarakat.

Upaya pembinaan dan pengembangan karakter di sekolah dapat dilakukan dengan beberapa metode, yaitu:

1. Metode langsung dan tidak langsung, Metode langsung berarti menyampaikanmateri pendidikan karakter (pendidikan akhlak) secara langsung dengan memberikan materi materi pelajaran akhlak. Metode tidak langsung adalah penanaman karakter anak melalui kisah-kisah yang mengandung nilainilai karakter mulia.

2. Melalui mata pelajaran tersendiri dan terintegrasi ke dalam semua mata pelajaran.

3. Melalui kegiatan diluar mata pelajaran, yaitu melalui pembiasaan atau pengembangan diri.

4. Melalui metode keteladanan. Keteladanan adalah metode yang sangat ampuh untuk pembinaan dan pengembangan karakter di sekolah. Contoh baik diberikan oleh kepala sekolah, guru merupakan metode ampuh dalam pembinaan dan pengembangan karakter di sekolah.

5. Melalui nasihat dan memberi perhatian. Memberikan pelajaran dengan cara yang baik melaui nasihat dan memberi perhatian dengan penuh kasih sayang akan menjadikan anak didik menjadi pribadi paripurna.

6. Metode reward dan punishment. Pemberian reward kepada siswa yang berprestasi akan membuat siswa tersebut berusaha lebih baik lagi st ' 'ian pemberian punishment adalah pemberian sanksi kepada anak namun harus tetap dengan kasih sayang agar anak tidak berani melakukan hal yang melanggar peraturan.

\section{KESIMPULAN}

Setelah menguraikan hasil penelitian di atas atas selanjutnya akan dikemukakan simpulan penelitian ini sebagai berikut:

1. Budaya sekolah memiliki hubungan positif dengan karakter siswa di Sekolah Dasar Negeri 050772 Pangkalan Susu. Hal ini dapat dilihat dari dinilai koefesien korelasi r $=0,504$. Nilai $r$ hitung lebih besar dari $r_{\text {tabel }}$ yaitu 0,3061. Niilai signifikansi yang 
dihasilkan lebih kecil dari 0,05 yaitu 0,004. Maka dapat disimpulkan bahwa $\mathrm{H}_{\mathrm{o}}$ ditolak dan $\mathrm{H}_{\mathrm{a}}$ diterima. Hal ini juga berarti bahwa terdapat hubungan yang positif antara budaya sekolah dengan karakter siswa. Berdasarkan hasil tersebut juga dinyatakan bahwa korelasi kedua variabel signifikan.

2. Keteladanan guru memiliki hubungan yang positif dengan karakter siswa Sekolah Dasar Negeri 050772 Pangkalan Susu. Hal ini dibuktikan dengan nilai r = 0,603.

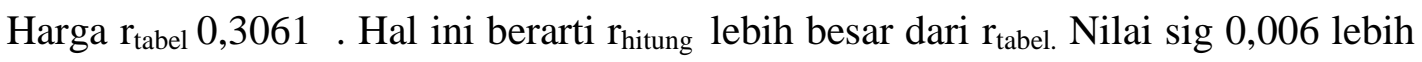
kecil dari 0,05, yang berarti bahwa persamaan regresi adalah signifikan.Maka dapat disimpulkan bahwa hipotesis nul $\left(\mathrm{H}_{0}\right)$ ditolak dan hipotesis alternatif $\left(\mathrm{H}_{\mathrm{a}}\right)$ diterima. Hal ini memberikan makna bahwa terdapat hubungan yang positif antara keteladanan guru dengan karakter siswa. Berdasarkan hasil tersebut dinyatakan bahwa korelasi kedua variabel signifikan.

3. Budaya sekolah dan keteladanan guru memiliki hubungan yang positif dengan karakter siswa. Hal ini dibuktikankoefesien korelasi $r=0,662$. Nilai $r$ hitung lebih besar dari $r_{\text {tabel }} 0,3061$. Dengan demikian korelasi antara variabel $X_{1}$ dan $X_{2}$ dengan $\mathrm{Y}$ adalah signifikan. Hal ini juga dibuktikan dengan hasil uji $\mathrm{F}$ yang menunjukkan bahwa $\mathrm{F}$ hitung adalah 15,982 lebih besar dari $\mathrm{F}$ tabel yaiti 3,35. Nilai signifikansi yang dihasilkan lebih kecil dari 0,05 yaitu 0,000. Maka dapat disimpulkan bahwa $\mathrm{H}_{\mathrm{o}}$ ditolak dan $\mathrm{H}_{\mathrm{a}}$ diterima. Hal ini juga berarti bahwa terdapat hubungan yang positif antara budaya sekolah dan keteladanan guru dengan karakter siswa pada taraf signifikansi 0,05. Berdasarkan hasil tersebut dapat dinyatakan bahwa korelasi variabel $\mathrm{X}_{1}$

dan $\mathrm{X}_{2}$ dengan $\mathrm{Y}$ signifikan.

Ketiga hipotesis yang diajukan dalam penelitian ini memberikan kesimpulan bahwa Budaya Sekolah dan Keteladanan Guru memiliki hubungan yang positif dengan Karakter Siswa Sekolah Dasar Negeri 050772 Pangkalan Susu.

\section{DAFTAR PUSTAKA}

Kamus Besar Bahasa Indonesia. 1996

Kementerian Pendidikan Nasional, Badan Penelitian dan Pengembangan, Pusat Kurikulum. Pengembangan Pendidikan Budaya dan Karakter Bangsa Pedoman Sekolah. Jakarta: Pusat Kurikulum. 2011

Marzuki. Pendidikan Karakter Islam. Jakarta: Imprint bumi Aksara. 2014 
Tim Penyusunan Kamus Pusat dan Pembinaan dan Pengembangan Bahasa Depdikbud, Kamus Besar Bahasa Indonesia. Jakarta: Balai Pustaka. 1994

Undang UndangNomor 20 tahun 2003 tentang Sistem Pendidikan Nasional

Undang-Undang Nomor 14 Tahun 2005 tentang Guru dan Dosen

Undang-Undang Republik Indonesia Nomor 17 Tahun 2007 tentang rencana pembangunan jangka panjang. Jakarta: Sekretariat Negara. 2007

Zubaedi. Desain Pendidikan Karakter (Konsepsi dan Aplikasiny dalam Lembaga Pendidikan). Jakarta: Kencana Prenada Media Group. 2013 